\title{
Raman Scattering Studies of Monohydrated L-Asparagine
}

\author{
A.J.D. Moreno* \\ Departamento de Física, \\ Universidade Federal do Maranhão, Campus do Bacanga \\ 65080-040 São Luís, MA - Brazil \\ P.T.C. Freire, I. Guedes, F.E.A. Melo, J. Mendes-Filho \\ Departamento de Física, Universidade Federal do Ceará \\ Campus do Pici, Caixa Postal 6030 \\ 60455-760, Fortaleza, CE - Brazil \\ and \\ J.A. Sanjurjo \\ Departamento de Eletrônica Quântica, IFGW-UNICAMP \\ Cidade Universitária, Caixa Postal 6165 \\ 13083-970, Campinas, SP - Brazil \\ Received 26 October, 1998
}

\begin{abstract}
Polarized first-order Raman scattering studies at $300 \mathrm{~K}$ were carried out in $\mathrm{L}$ - asparagine monohydrate crystal in order to obtain the general assignment of its phonon spectra. A careful analysis of the vibrational spectra shows that the assignment of the fundamental vibrational modes can be done on the basis of amino, carboxilic and water groups vibrations, and correlations with previous data reported for other amino acids. However, some vibrations were correctly assigned from the study of its temperature - dependence behavior performed in the range $10-300 \mathrm{~K}$. The assignment proposed confirm the zwitterionic structure of L-asparagine monohydrate crystal.
\end{abstract}

\section{Introduction}

Amino acids are the molecular building blocks of peptides and proteins. The structure adopted by amino acids, after condensation into larger units, effectively determines their secondary structure in crystalline samples. Studies of vibrational spectra of amino acids by Raman and infrared spectroscopies are useful in obtaining information regarding the molecular conformation and the nature of hydrogen bonding in these biologically important substances.

Among other biological substances, asparagine is a very important amino acid because it plays a role in the metabolic control of some cell functions in nerve and brain tissue, and is also used by many plants as a nitrogen reserve source [1]. However, despite its biological interest, there are few works published in the literature concerning to investigation of fundamental vibrations of asparagine compounds and its derivatives [2,3]. For instance, Casado et al. [3] presented a detailed study of the anhydrous asparagine $\left[\mathrm{NH}_{2} \mathrm{CO}\left(\mathrm{CH}_{2}\right) \mathrm{CH}\left(\mathrm{NH}_{3}^{+}\right) \mathrm{COO}^{-}\right]$, Asn- $\mathrm{h}_{5}$, and deuterated anhydrous asparagine $\left[\mathrm{ND}_{2} \mathrm{CO}\left(\mathrm{CH}_{2}\right) \mathrm{CH}\left(\mathrm{ND}_{3}^{+}\right) \mathrm{COO}^{-}\right]$, Asn- $\mathrm{d}_{5}$, as microcrystalline powder samples, using unpolarized Raman scattering and infrared absorption techniques. Although no data on the molecular structure of Asn- $\mathrm{h}_{5}$ and Asn - $\mathrm{d}_{5}$ are known, the authors have assumed the usual zwitterionic structure, suported by X-ray and neutron diffraction studies on L-asparagine monohydrate $\left[\mathrm{NH}_{2} \mathrm{CO}\left(\mathrm{CH}_{2}\right) \mathrm{CH}\left(\mathrm{NH}_{2}\right) \mathrm{COOH} \cdot \mathrm{H}_{2} \mathrm{O}\right]$, MLA [4]. A general assignment for the fundamental vibrations of these

*e-mail: jeferson@ufma.br 
molecules was proposed on the basis of the isotopic shifts and correlations with similar amino acids.

Surprisingly, up to 1997 no one had investigated the fundamental vibrational modes of MLA as crystalline sample and its structural modifications under uniaxial or hydrostatic pressure. Recently, we have studied MLA by Raman spectroscopy in a diamond-anvil cell up to pressures of $2.0 \mathrm{Gpa}$ at $300 \mathrm{~K}$ [5]. From the analysis of results we observed that MLA undergoes a series of three phase transitions. All these are characterized by drastic changes in the external modes and some internal ones of MLA, which clearly shows the transitions induced by hydrostatic pressure. As a continuation of this study, here we present for the first time a detailed investigation on the fundamental vibration spectrum of MLA at $300 \mathrm{~K}$ in the frequency range $50-3600 \mathrm{~cm}^{-1}$ through polarized Raman scattering technique. Data obtained from Raman spectra taken at several temperatures in the range $10-300 \mathrm{~K}[6]$ and correlations with others amino acis were used to propose a general assignment of the vibration modes of MLA at room temperature.

\section{Experimental}

Single crystals of MLA were grown from acqueous solution containing untreated L-asparagine monohydrate powder furnished by Vetec,Co., by slow evaporation at $\mathrm{T}=278 \mathrm{~K}$. The crystals obtained were prisms, elongated along the a-axis and bounded by $\{011\}$ planes. The samples used in the experiments were selected using a polarizing microscope and $\mathrm{X}$-ray diffacttion data. They were cut into parallelepipeds with dimensions $4 \times 4 \times 6 \mathrm{~mm}^{3}$ and polished on Metchoth cloth using diamond paste.

The excitation source in the Raman experiments was a $514.5 \mathrm{~nm}$ radiation Spectra Physics argon ion laser (Model 2020) working at $80 \mathrm{mw}$, and the scattered light was analysed using a Jobin-Yvon Triplemate 64000 spectrometer equipped with $\mathrm{N}_{2}$ - cooled CCD system. The slits were set for a $1 \mathrm{~cm}^{-1}$ spectral resolution.

\section{Crystal structure and fac- tor group analysis}

Similarly to many other amino acids, MLA molecule occurs in the dipolar form $\left({ }^{+} \mathrm{H}_{3} \mathrm{~N} \cdot \mathrm{CHR} \cdot \mathrm{COO}^{-} \mathrm{H}_{2} \mathrm{O}\right)$.
According to Ref. [4], at 300 K MLA crystallizes in an orthorhombic system belonging to space group P2 $2_{1} 2_{1} 2_{1}\left(\mathrm{D}_{2}^{4}\right)$ with lattice parameters a $=5.582 \AA$, $\mathrm{b}=9.812 \AA$ And $\mathrm{c}=11.796 \AA$, and four molecules per unit cell which occupy general sites of $\mathrm{C}_{1}$ symmetry. No intramolecular hydrogen bonds have been found. The structure is stabilized by a complex network of seven intermolecular hydrogen bonds involving all the hydrogen atoms bound to oxygen and nitrogen ones. From the correlation diagram the 237 zone-center optical modes vibrations are seen to decompose into

$$
\Lambda=60 A+59\left(B_{1}+B_{2}+B_{3}\right)
$$

where 162 modes are optical translatory- and rotatorytype ones, whereas 72 modes are due to internal vibrations. Phonons belonging to A symmetry are Raman active but infrared inactive, whereas phonon belonging to B symmetries are both infrared and Raman active. The polarized Raman spectra were obtained following the traditional notation of Tell et al [7]. Phonons belonging to A symmetry were observed in the $\mathrm{a}(\mathrm{cc}) \mathrm{b}$ geometry, while the $B_{1}, B_{2}$ and $B_{3}$ modes correspond to $\mathrm{b}(\mathrm{ab}) \mathrm{c}, \mathrm{c}(\mathrm{ac}) \mathrm{b}$ and $\mathrm{a}(\mathrm{bc}) \mathrm{b}$ configurations, respectively.

\section{Results and discussion}

Following the usual procedure, the assignments are discussed in four regions, namely: (i) high-wavenumber region (2800 - $3600 \mathrm{~cm}^{-1}$ ); (ii) medium-wavenumber region (1050 - $1800 \mathrm{~cm}-1)$; (iii) low-wavenumber region (190 - $\left.1000 \mathrm{~cm}^{-1}\right)$; and (iv) lattice vibration region ( below $190 \mathrm{~cm}^{-1}$ ).

\section{High-wavenumber region}

It is observed from Fig. 1 that this spectral region contains some very broad bands. Such a situation is usually found in crystals which present vibration modes associated to hydrogen bonds. In this region we can assign the $\mathrm{NH}_{2}, \mathrm{NH}_{3}^{+}, \mathrm{CH}, \mathrm{CH}_{2}$ and $\mathrm{H}_{2} \mathrm{O}$ stretching vibrations. The following discussion is based on $\mathrm{B}_{2}$ symmetry modes. However, the bands located at 3264 $\mathrm{cm}^{-1}$ and $2921 \mathrm{~cm}^{-1}$ are analyzed from $B_{1}$ species. The observed wavenumbers, relative intensities and the proposed assignment for the vibrations in this spectral region are listed in Table 1. 
TABLE 1. Experimental wavenumbers from the vibration spectra of MLA at $300 \mathrm{~K}$ in the frequency range $3600-2800 \mathrm{~cm}^{-1}$.

\begin{tabular}{llllllc}
\hline $\mathrm{z}(\mathrm{xx}) \mathrm{y}$ & $\mathrm{x}(\mathrm{yy}) \mathrm{z}$ & $\mathrm{y}(\mathrm{zz}) \mathrm{x}$ & $\mathrm{y}(\mathrm{xy}) \mathrm{x}$ & $\mathrm{y}(\mathrm{xz}) \mathrm{x}$ & $\mathrm{z}(\mathrm{yz}) \mathrm{x}$ & assignment \\
\hline $3423 \mathrm{vw}$ & $3423 \mathrm{vw}$ & $3423 \mathrm{vw}$ & $3461 \mathrm{w}$ & $3447 \mathrm{w}$ & $3441 \mathrm{w}$ & $\nu_{a}\left(\mathrm{H}_{2} \mathrm{O}\right)$ \\
$3401 \mathrm{~s}$ & $3401 \mathrm{~s}$ & $3401 \mathrm{~s}$ & - & $3407 \mathrm{~s}$ & $3404 \mathrm{w}$ & $\nu_{s}\left(\mathrm{H}_{2} \mathrm{O}\right)$ \\
$3385 \mathrm{~s}$ & $3385 \mathrm{~s}$ & $3385 \mathrm{~s}$ & $3387 \mathrm{~s}$ & $3388 \mathrm{vs}$ & - & $\nu_{a}\left(\mathrm{NH}_{2}\right)$ \\
$3252 \mathrm{vw}$ & $3252 \mathrm{vw}$ & $3252 \mathrm{vw}$ & $3264 \mathrm{w}$ & $3248 \mathrm{vw}$ & - & $\nu_{s}\left(\mathrm{NH}_{2}\right)$ \\
- & - & - & $3115 \mathrm{~s}$ & $3117 \mathrm{~m}$ & $3109 \mathrm{~s}$ & $\nu_{a}\left(\mathrm{NK}_{3}^{+}\right)$ \\
$3099 \mathrm{w}$ & $3099 \mathrm{w}$ & $3099 \mathrm{w}$ & - & $3093 \mathrm{~s}$ & - & $\nu_{a}\left(\mathrm{NK}_{3}^{+}\right)$ \\
$2966 \mathrm{vs}$ & $2966 \mathrm{vs}$ & $2966 \mathrm{vs}$ & $2966 \mathrm{~s}$ & $2965 \mathrm{vw}$ & $2965 \mathrm{~s}$ & $\nu_{a}\left(\mathrm{CH}_{2}\right)$ \\
$2958 \mathrm{~s}$ & $2958 \mathrm{~s}$ & $2958 \mathrm{~s}$ & $2957 \mathrm{~s}$ & $2956 \mathrm{vw}$ & $2956 \mathrm{vw}$ & $\nu\left(\mathrm{CH}^{2}\right)$ \\
$2935 \mathrm{vs}$ & $2935 \mathrm{vs}$ & $2935 \mathrm{vs}$ & $2933 \mathrm{vs}$ & $2933 \mathrm{vw}$ & $2934 \mathrm{w}$ & $\nu_{s}\left(\mathrm{CH}_{2}\right)$ \\
- & - & - & $2921 \mathrm{sh}$ & - & - & $\nu_{s}\left(\mathrm{NK}_{3}^{+}\right)$ \\
\hline s = strong; & w = weak; & $\mathrm{v}=$ very and & sh $=$ shoulder & & \\
\hline
\end{tabular}

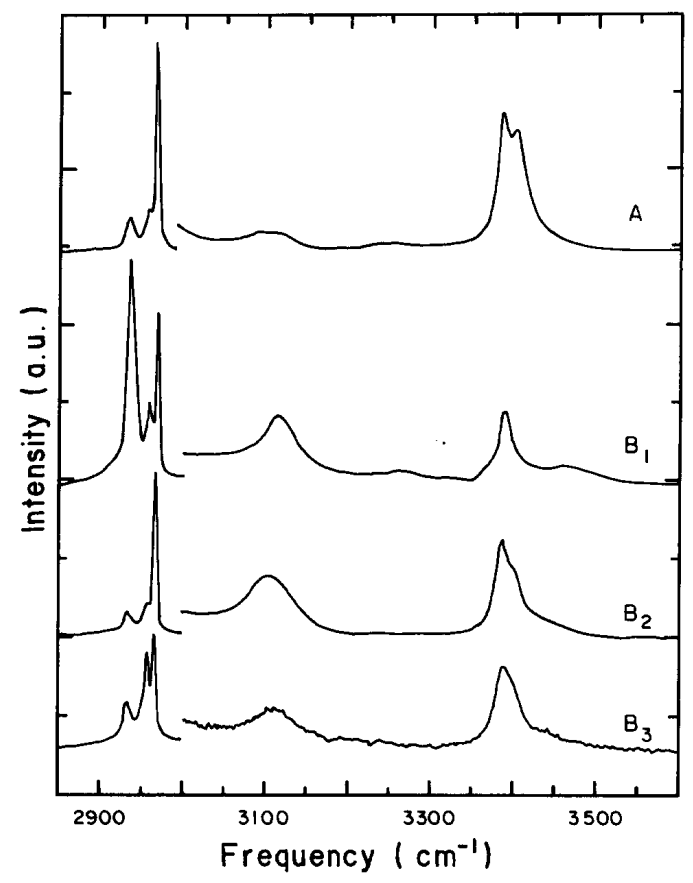

Figure 1. Polarized Raman spectra of MLA in the frequency range $3600-2800 \mathrm{~cm}^{-1}$.

It is well known that the free water molecule $\left(\mathrm{H}_{2} \mathrm{O}\right)$ has characteristic stretching frequencies at 3652 and $3756 \mathrm{~cm}^{-1}$ [8]. Due to the hydrogen bonds the effective force between $\mathrm{O}$ and $\mathrm{H}$ atoms in the $\mathrm{H}_{2} \mathrm{O}$ molecule is reduced, and then the $\mathrm{H}_{2} \mathrm{O}$ stretching wavenumbers in MLA crystal should present lower value than in the free molecule. In accordance with Casado et al. [3], the Raman spectrum of Asn- $\mathrm{h}_{5}$ shows two characteristic bands corresponding to the asymmetric $\left(\nu_{a}\right)$ and symmetric $\left(\nu_{s}\right) \mathrm{NH}_{2}$ stretching vibrations located at 3388 $\mathrm{cm}^{-1}$ and $3248 \mathrm{~cm}^{-1}$, respectively. Therefore, the band centered about $3390 \mathrm{~cm}^{-1}$ should contain three peaks corresponding to $\nu_{1}\left(\mathrm{H}_{2} \mathrm{O}\right), \nu_{3}\left(\mathrm{H}_{2} \mathrm{O}\right)$ and $\nu_{a}\left(\mathrm{NH}_{2}\right)$ vibrations. In order to verify this assumption we have performed a lorentzian fitting as shown in Fig. 2. The fitting yields $\nu_{1}\left(\mathrm{H}_{2} \mathrm{O}\right)=3447 \mathrm{~cm}^{-1}, \nu_{3}\left(\mathrm{H}_{2} \mathrm{O}\right)=3407$ $\mathrm{cm}^{-1}$ and $\nu_{a}\left(\mathrm{NH}_{2}\right)=3388 \mathrm{~cm}^{-1}$. The $\nu_{s}\left(\mathrm{NH}_{2}\right)$ vibration is observed at $3248 \mathrm{~cm}^{-1}$. This band is very weak for all investigated scattering geometries. Its classification was done based on the temperature dependent Raman spectra, where for temperatures below $200 \mathrm{~K}$ this band can be clearly seen [6].

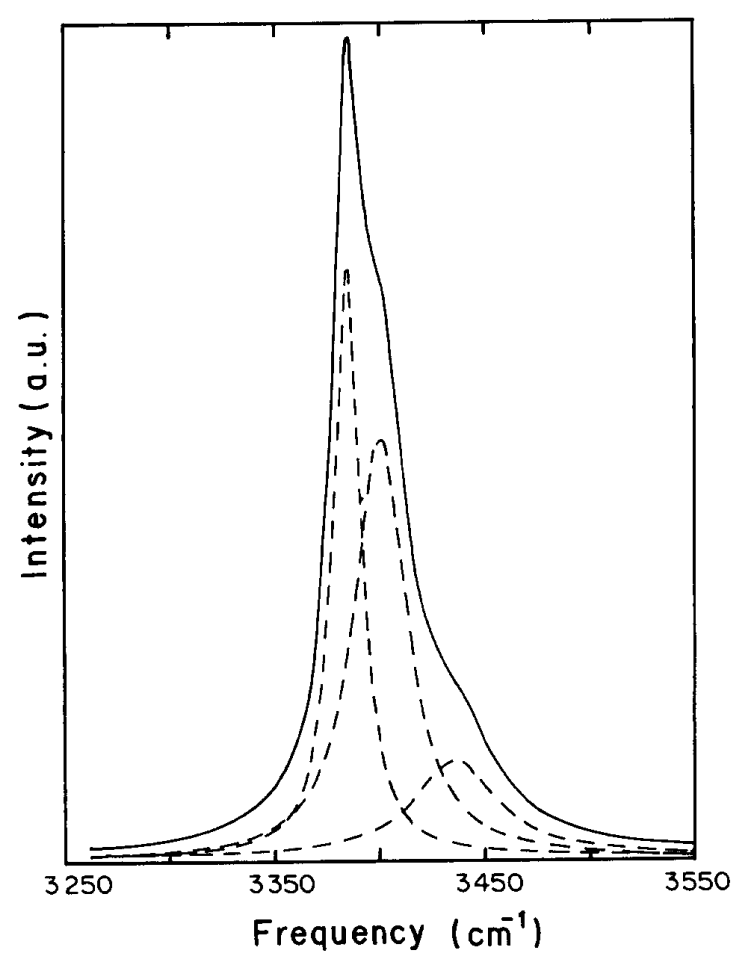

Figure 2. Lorentzian fittings of the bands appearing in the frequency range $3450-3380 \mathrm{~cm}^{-1}$ for B2 symmetry modes. 
In amino acids [9] and amino sulphones [10], the stretching vibrations of the $\mathrm{NH}_{3}^{+}$group are expected in the frequency region $3150-3000 \mathrm{~cm}^{-1}$. These modes are usually observed as weak bands and it is somewhat difficult to assign them when other $\mathrm{NH}$ or $\mathrm{CH}$ intense bands are present in the vibrational spectra. For MLA we assigned the $\nu_{a}\left(\mathrm{NH}_{3}^{+}\right)$degenerated vibration to the band centered at $3110 \mathrm{~cm}^{-1}$. In fact, if we use a lorentzian fitting, we can observe that there are two nondegenerated $\nu_{a}\left(\mathrm{NH}_{3}^{+}\right)$at $3117 \mathrm{~cm}^{-1}$ and 3093 $\mathrm{cm}^{-1}$. These assignments were mainly based on previous work on the L-alanine crystal [9]. The splitting of two-fold degenerated $\nu_{a}\left(\mathrm{NH}_{3}^{+}\right)$mode can be explained taking into account the lowering from $\mathrm{C}_{3 \nu}$ symmetry of the free $\mathrm{NH}_{3}^{+}$group to $\mathrm{C}_{1}$ symmetry in the crystal environment of MLA. In order to correctly assign the $\nu_{s}$ $\left(\mathrm{NH}_{3}^{+}\right)$we analyze its temperature-dependent behavior in the range $10-300 \mathrm{~K}$ [6]. At $10 \mathrm{~K}$, we observed, besides three $\mathrm{CH}$ stretching vibrations, the appearance of a vibration around $2925 \mathrm{~cm}^{-1}$. Its integrated scattered intensity remains constant with increasing or decreasing temperature. In this way, it can not be attributed to a Fermi resonance enhanced overtone or an overlapping between fundamental modes. Hence, this vibration should be assigned to $\nu_{s}\left(\mathrm{NH}_{3}^{+}\right)$. At $300 \mathrm{~K}$, we have assigned the $\nu_{s}\left(\mathrm{NH}_{3}^{+}\right)$to the shoulder measured at $2921 \mathrm{~cm}^{-1}$. For Asn- $\mathrm{h}_{5}$, Casado et al. [3] have assigned the $\nu_{s}\left(\mathrm{NH}_{3}^{+}\right)$vibration to the shoulder measured at $3025 \mathrm{~cm}^{-1}$ from the infrared spectrum. No assignment of this mode is proposed from Raman spectrum. However, from Fig. 3 of Ref. [3], we observe that there is a vibration mode at $2860 \mathrm{~cm}^{-1}$. When Asn- $\mathrm{h}_{5}$ is deuterated (Asn- $\mathrm{d}_{5}$ ), this vibration disappears (cf. Fig. 4 of Ref. [3] ). This result suggests that the vibration at $2860 \mathrm{~cm}^{-1}$ observed by Casado et al. [3] should be related to $\nu_{s}\left(\mathrm{NH}_{3}^{+}\right)$, which agrees with our observations.

The three $\mathrm{C}-\mathrm{H}$ stretching modes observed in the frequency range $2900-3000 \mathrm{~cm}^{-1}$ are assigned following the same order as for aspartic acid [11], that is, $\nu(\mathrm{CH})$ is between the $\nu_{a}\left(\mathrm{CH}_{2}\right)$ at $2965 \mathrm{~cm}^{-1}$ and the $\nu_{s}\left(\mathrm{CH}_{2}\right)$ at $2934 \mathrm{~cm}^{-1}$. The wavenumber for the methylene stretching vibration, $2956 \mathrm{~cm}^{-1}$, compares well with those reported for other amino acids such as l-alanine, $2962 \mathrm{~cm}^{-1}$ [9], cysteine, $2968 \mathrm{~cm}^{-1}$ [12], and also with Asn- $\mathrm{h}_{5}, 2977 \mathrm{~cm}^{-1}$ [3].

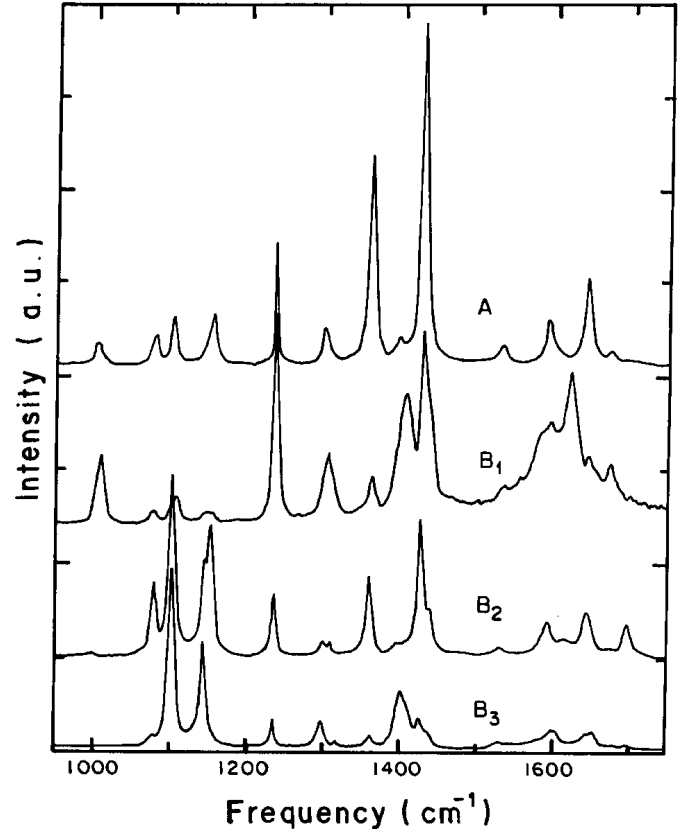

Figure 3. Polarized Raman spectra of MLA in the frequency range $1800-900 \mathrm{~cm}^{-1}$.

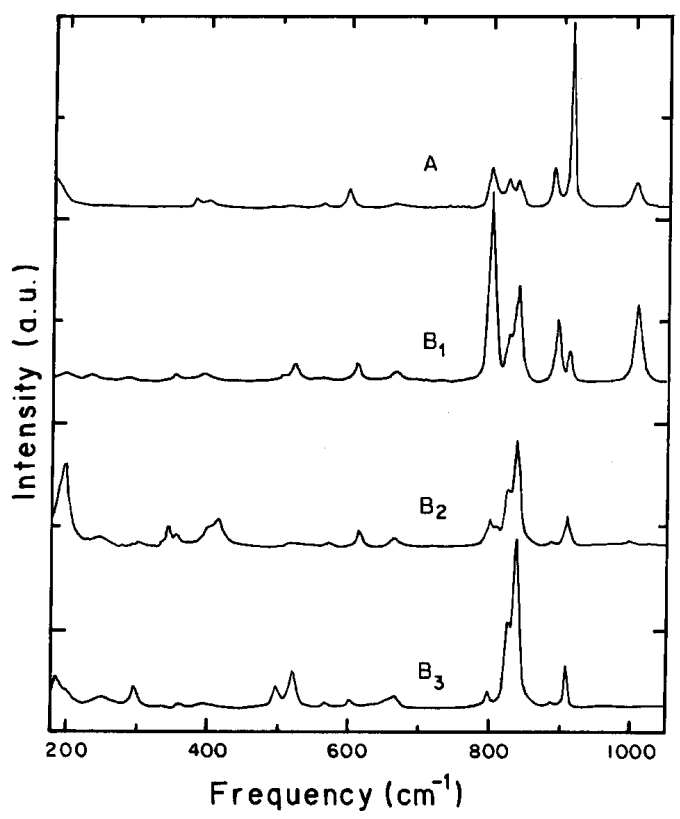

Figure 4. Polarized Raman spectra of MLA in the frequency range $900-190 \mathrm{~cm}^{-1}$.

\section{Medium-wavenumber region}

From Fig. 3, we observe that this spectral region presents a large number of normal modes. The bands 
are very broad for all scattering geometries. Due to this fact, the assignment of the normal modes was performed with the help of lorentzian fittings. The discussion of this frequency region is based mainly on the $B_{1}$ representation, excepting the modes at $1694 \mathrm{~cm}^{-1}$ and
$1594 \mathrm{~cm}^{-1}$ which are observed from $B_{2}$ and $B_{3}$ geometries. The measured wavenumbers, relative intensities and proposed assignments for the bands observed in this region are summarized in Table 2.

TABLE 2. Experimental wavenumbers from the vibration spectra of MLA at $300 \mathrm{~K}$ in the frequency range $1800-900 \mathrm{~cm}^{-1}$.

\begin{tabular}{lllllll}
\hline $\mathrm{z}(\mathrm{xx}) \mathrm{y}$ & $\mathrm{x}(\mathrm{yy}) \mathrm{z}$ & $\mathrm{y}(\mathrm{zz}) \mathrm{x}$ & $\mathrm{y}(\mathrm{xy}) \mathrm{x}$ & $\mathrm{y}(\mathrm{xz}) \mathrm{x}$ & $\mathrm{z}(\mathrm{yz}) \mathrm{x}$ & assignment \\
\hline- & - & - & - & $1696 \mathrm{~s}$ & $1694 \mathrm{vw}$ & $\delta_{a}\left(\mathrm{NK}_{3}^{+}\right)$ \\
$1670 \mathrm{vw}$ & $1670 \mathrm{vw}$ & $1670 \mathrm{vw}$ & $1673 \mathrm{~s}$ & $1672 \mathrm{vw}$ & $1669 \mathrm{vw}$ & $\delta_{a}\left(\mathrm{NK}_{3}^{+}\right)$ \\
$1644 \mathrm{vw}$ & $1644 \mathrm{vw}$ & $1644 \mathrm{vw}$ & $1647 \mathrm{~s}$ & $1644 \mathrm{vw}$ & $1645 \mathrm{w}$ & $\nu(\mathrm{C}=\mathrm{O})$ \\
$1630 \mathrm{~s}$ & $1631 \mathrm{~s}$ & $1631 \mathrm{~s}$ & $1621 \mathrm{vw}$ & $1617 \mathrm{w}$ & - & $\delta\left(\mathrm{NH}_{2}\right)$ \\
$1594 \mathrm{vw}$ & $1594 \mathrm{vw}$ & $1594 \mathrm{vw}$ & - & $1594 \mathrm{~s}$ & $1600 \mathrm{vw}$ & $\delta\left(\mathrm{H}_{2} \mathrm{O}\right)$ \\
- & - & - & $1580 \mathrm{~s}$ & - & $1582 \mathrm{vw}$ & $\nu_{a}\left(\mathrm{CO}_{2}^{-}\right)$ \\
- & - & - & $1534 \mathrm{vw}$ & $1531 \mathrm{w}$ & $1534 \mathrm{vw}$ & $\delta_{s}\left(\mathrm{NK}_{3}^{+}\right)$ \\
$1435 \mathrm{~s}$ & $1435 \mathrm{~s}$ & $1436 \mathrm{~s}$ & $1435 \mathrm{w}$ & $1438 \mathrm{w}$ & $1436 \mathrm{vw}$ & $\delta_{a}\left(\mathrm{CH}_{2}\right)$ \\
- & - & - & $1428 \mathrm{~s}$ & $1426 \mathrm{w}$ & $1426 \mathrm{w}$ & $\nu_{s}\left(\mathrm{CO}_{2}^{-}\right)$ \\
$1409 \mathrm{w}$ & $1409 \mathrm{w}$ & $1409 \mathrm{w}$ & $1407 \mathrm{vw}$ & - & $1409 \mathrm{w}$ & $\delta\left(\mathrm{CN}^{-}\right)$ \\
$1396 \mathrm{vw}$ & $1396 \mathrm{vw}$ & $1396 \mathrm{vw}$ & $1399 \mathrm{~s}$ & $1400 \mathrm{vw}$ & $1400 \mathrm{vw}$ & $\delta_{s}\left(\mathrm{CH}_{2}\right)$ \\
$1363 \mathrm{~s}$ & $1363 \mathrm{~s}$ & $1362 \mathrm{~s}$ & $1362 \mathrm{vw}$ & $1359 \mathrm{vw}$ & $1361 \mathrm{vw}$ & $\delta\left(\mathrm{CH}^{2}\right)$ \\
- & - & - & $1304 \mathrm{w}$ & $1310 \mathrm{vw}$ & $1318 \mathrm{vw}$ & $\delta\left(\mathrm{CH}^{2}\right)$ \\
$1301 \mathrm{vw}$ & $1302 \mathrm{vw}$ & $1301 \mathrm{vw}$ & $1299 \mathrm{vw}$ & $1300 \mathrm{vw}$ & $1299 \mathrm{vw}$ & $\omega\left(\mathrm{NH}_{2}\right)$ \\
$1238 \mathrm{~s}$ & $1237 \mathrm{~s}$ & $1237 \mathrm{~s}$ & $1237 \mathrm{~s}$ & $1236 \mathrm{~s}$ & $1237 \mathrm{vw}$ & $\tau\left(\mathrm{CH}_{2}\right)$ \\
- & - & - & - & $1153 \mathrm{~s}$ & $1154 \mathrm{vw}$ & $\mathrm{r}\left(\mathrm{NH}_{2}\right)$ \\
$1147 \mathrm{vw}$ & $1147 \mathrm{vw}$ & $1146 \mathrm{vw}$ & $1148 \mathrm{w}$ & $1145 \mathrm{vw}$ & $1141 \mathrm{vw}$ & $\mathrm{r}\left(\mathrm{NK}_{3}^{+}\right)$ \\
$1109 \mathrm{~s}$ & $1109 \mathrm{~s}$ & $1109 \mathrm{~s}$ & $1104 \mathrm{vw}$ & $1102 \mathrm{~s}$ & $1102 \mathrm{w}$ & $\mathrm{r}\left(\mathrm{NK}_{3}^{+}\right)$ \\
$1075 \mathrm{~s}$ & $1074 \mathrm{~s}$ & $1075 \mathrm{~s}$ & $1076 \mathrm{w}$ & $1078 \mathrm{~s}$ & $1077 \mathrm{w}$ & $\nu\left(\mathrm{CN}^{2}\right)$ \\
\hline $\mathrm{s}=\mathrm{strong} ;$ & $\mathrm{w}=\mathrm{weak} ;$ & $\mathrm{v}=\mathrm{very}$ and & $\mathrm{sh}=\mathrm{shoulder}$ & & &
\end{tabular}

It is well known that ionized carboxilic group $\left(\mathrm{COO}^{-}\right)$have two characteristic bands in this frequency range, namely: (i) $\nu_{a}$ at $1600 \mathrm{~cm}^{-1}$, and (ii) $\nu_{s}$ at 1400 $\mathrm{cm}^{-1}$. Since MLA presents $\mathrm{COO}^{-}$and $\mathrm{CONH}_{2}$ groups, a band related to $\nu(\mathrm{C}=\mathrm{O})$ stretching vibration should also appear in this wavenumber region. The bands due to vibrations of $\mathrm{NH}_{3}^{+}, \mathrm{CO}_{2}^{-}$and $\mathrm{NH}_{2}$ groups obey some hierarchical wavenumber relationship and then we can do a tentative assignment for these modes.

In the frequency range $1500-1700 \mathrm{~cm}^{-1}$ we observe from all scattering geometries, seven vibrational modes. The highest wavenumber bands in this region 1694 and $1673 \mathrm{~cm}^{-1}$, were assigned to asymmetric bendings of $\mathrm{NH}_{3}^{+}\left(\delta_{a}\right)$, while the related symmetric bending of $\mathrm{NH}_{3}^{+}\left(\delta_{s}\right)$ was observed at $1534 \mathrm{~cm}^{-1}$. The asymmetric stretching vibrations of the carboxylate group are is observed at $\nu_{a}\left(\mathrm{COO}^{-}\right)=1580 \mathrm{~cm}^{-1}$. The $\nu(\mathrm{C}=\mathrm{O})$ mode appears as the most intense band at $1647 \mathrm{~cm}^{-1}$ for $B_{1}$ species. Close to this band we have assigned the following vibrations: (i) $\delta\left(\mathrm{NH}_{2}\right)$ at $1621 \mathrm{~cm}^{-1}$; and (ii) $\delta\left(\mathrm{H}_{2} \mathrm{O}\right)$ at $1594 \mathrm{~cm}^{-1}$.

In the frequency range $1050-1500 \mathrm{~cm}^{-1}$ we observe twelve bands. From these, there are six bands which depend weakly on the temperature [6]. They are due to vibrations of groups not linked by hydrogen bonds. These bands are: (i) $\delta_{a}\left(\mathrm{CH}_{2}\right)$ at $1435 \mathrm{~cm}^{-1}$; (ii) one due to wagging-type vibration ( $\omega)$ of $\mathrm{CH}_{2}$ group at 1299 $\mathrm{cm}^{-1}$; (iii) one due to torsion-type vibration $(\tau)$ of $\mathrm{CH}_{2}$ group at $1237 \mathrm{~cm}^{-1}$; (iv) $\delta_{s}\left(\mathrm{CH}_{2}\right)$ at $1399 \mathrm{~cm}^{-1}$; and (v) two $\delta(\mathrm{CH})$ at 1362 and $1304 \mathrm{~cm}^{-1}$. These assignments compare well with those reported for glutamic acid [12] and Asn-h $\mathrm{h}_{5}[3]$. 
The remainder six bands which depend on temperature are: (i) one due to symmetric stretching of the carboxylate group observed at $\nu_{s}\left(\mathrm{COO}^{-}\right)=1428 \mathrm{~cm}^{-1}$; (ii) two due to rocking-type (r) vibrations of $\mathrm{NH}_{3}^{+}$group at 1142 and $1102 \mathrm{~cm}^{-1}$; (iii) one $\mathrm{r}\left(\mathrm{NH}_{2}\right)$ at $1154 \mathrm{~cm}^{-1}$; and finally (iv) two $\nu(\mathrm{CN})$ at 1409 and $1077 \mathrm{~cm}^{-1}$. For the sake of comparison, the $\mathrm{r}\left(\mathrm{NH}_{3}^{+}\right)$modes were observed at 1152 and $1120 \mathrm{~cm}^{-1}$ for aspartic acid [11] and at 1138 and $1119 \mathrm{~cm}^{-1}$ for glycine [13], whereas $\mathrm{r}\left(\mathrm{NH}_{2}\right)$ was reported at $1162 \mathrm{~cm}^{-1}$ for glutamine [14] and at $1149 \mathrm{~cm}^{-1}$ for acetamide [15]. Also, Diem et al [9] observed that $\nu(\mathrm{CC})$ stretching vibration of $\mathrm{L}$ alanine takes place around $1000 \mathrm{~cm}^{-1}$, which is in good agreement with our result.

\section{Low-wavenumber region}

In this region we expect to be able to identify besides the $\mathrm{C}-\mathrm{C}$ stretching modes, the rest of the bending vibrations along with the torsional and skeletal stretching modes. The Raman spectra for the four scattering geometries are shown in Fig. 4. The discussion of the mode assignment is performed mainly on $B_{3}$ representation, excepting the $807 \mathrm{~cm}^{-1}$ mode which is observed only in the $B_{2}$ representation. The results are reported in Table 3.

TABLE 3. Experimental wavenumbers from the vibration spectra of MLA at $300 \mathrm{~K}$ in the frequency range $900-190 \mathrm{~cm}^{-1}$.

\begin{tabular}{|c|c|c|c|c|c|c|}
\hline$z(x x) y$ & $\mathrm{x}(\mathrm{yy}) \mathrm{z}$ & $\mathrm{y}(\mathrm{zz}) \mathrm{x}$ & $y(x y) x$ & $y(x z) x$ & $\mathrm{z}(\mathrm{yz}) \mathrm{x}$ & assignment \\
\hline- & - & - & $1008 \mathrm{~s}$ & - & $1004 \mathrm{w}$ & $\nu(\mathrm{CC})$ \\
\hline $910 \mathrm{vw}$ & $911 \mathrm{vw}$ & $911 \mathrm{vw}$ & $911 \mathrm{w}$ & $909 \mathrm{w}$ & $913 \mathrm{~s}$ & $\nu(\mathrm{CC})$ \\
\hline $890 \mathrm{w}$ & $890 \mathrm{w}$ & $889 \mathrm{w}$ & $894 \mathrm{w}$ & $886 \mathrm{w}$ & $888 \mathrm{w}$ & $\nu(\mathrm{CC})$ \\
\hline $841 \mathrm{~s}$ & $841 \mathrm{~s}$ & $841 \mathrm{~s}$ & $839 \mathrm{~s}$ & $838 \mathrm{~s}$ & $838 \mathrm{w}$ & $\gamma\left(\mathrm{NH}_{2}\right)$ \\
\hline $825 \mathrm{~s}$ & $825 \mathrm{~s}$ & $825 \mathrm{~s}$ & $826 \mathrm{w}$ & $825 \mathrm{w}$ & $823 \mathrm{w}$ & $\gamma\left(\mathrm{CO}_{2}^{-}\right)$ \\
\hline- & - & - & - & $807 \mathrm{w}$ & - & $\gamma\left(\mathrm{H}_{2} \mathrm{O}\right)$ \\
\hline $800 \mathrm{~s}$ & $800 \mathrm{~s}$ & $800 \mathrm{~s}$ & $800 \mathrm{~s}$ & $799 \mathrm{w}$ & $799 \mathrm{w}$ & $\mathrm{r}\left(\mathrm{CH}_{2}\right)$ \\
\hline $669 \mathrm{w}$ & $668 \mathrm{w}$ & $669 \mathrm{w}$ & $665 \mathrm{~s}$ & $667 \mathrm{w}$ & $664 \mathrm{~s}$ & $\delta_{a}\left(\mathrm{CONH}_{2}\right)$ \\
\hline- & - & - & - & - & $648 \mathrm{w}$ & $\delta_{a}\left(\mathrm{CO}_{2}^{-}\right)$ \\
\hline $602 \mathrm{w}$ & $602 \mathrm{w}$ & $602 \mathrm{w}$ & $602 \mathrm{~s}$ & $609 \mathrm{~s}$ & $603 \mathrm{w}$ & $\delta_{s}\left(\mathrm{CONH}_{2}\right)$ \\
\hline $564 \mathrm{~s}$ & $564 \mathrm{~s}$ & $565 \mathrm{~s}$ & $568 \mathrm{w}$ & $565 \mathrm{w}$ & $569 \mathrm{w}$ & $\delta_{s}\left(\mathrm{CO}_{2}^{-}\right)$ \\
\hline $530 \mathrm{~s}$ & $531 \mathrm{~s}$ & $530 \mathrm{~s}$ & $522 \mathrm{~s}$ & - & $521 \mathrm{~s}$ & $\tau\left(\mathrm{NH}_{2}\right)$ \\
\hline $495 \mathrm{w}$ & $494 \mathrm{w}$ & $495 \mathrm{w}$ & $504 \mathrm{w}$ & $507 \mathrm{w}$ & $498 \mathrm{~s}$ & $\delta$ (struct) \\
\hline $401 \mathrm{w}$ & $401 \mathrm{w}$ & $402 \mathrm{w}$ & - & $407 \mathrm{~s}$ & $402 \mathrm{w}$ & $\delta$ (struct) \\
\hline $390 \mathrm{w}$ & $389 \mathrm{w}$ & $389 \mathrm{w}$ & $394 \mathrm{w}$ & $390 \mathrm{~s}$ & $386 \mathrm{w}$ & $\tau\left(\mathrm{NK}_{3}^{+}\right)$ \\
\hline $339 \mathrm{~s}$ & $340 \mathrm{~s}$ & $340 \mathrm{~s}$ & $353 \mathrm{w}$ & $351 \mathrm{w}$ & $360 \mathrm{w}$ & $\delta($ struct $)$ \\
\hline- & - & - & - & $295 \mathrm{w}$ & $290 \mathrm{w}$ & $\delta($ struct $)$ \\
\hline- & - & $244 \mathrm{w}$ & $238 \mathrm{w}$ & $242 \mathrm{w}$ & $250 \mathrm{w}$ & $\delta($ struct $)$ \\
\hline $\mathrm{s}=$ strong; & w = weak; & $\mathrm{v}=$ very and & sh $=$ shoulder & & & \\
\hline
\end{tabular}

According to Ref. [16], the symmetric stretchings of $\mathrm{C}-\mathrm{C}$ and/or C-C-N structures appear in the frequency range $750-1000 \mathrm{~cm}^{-1}$ of the vibrational spectra of several amino acids. The modes observed at 1004, 913 and $888 \mathrm{~cm}^{-1}$ were assigned as the $\nu(\mathrm{CC})$ vibrations. Near them we also expect to observe one methylene rocking vibration $\left(\mathrm{r}\left(\mathrm{CH}_{2}\right)\right)$, one out-of-plane vibration of amide group $\left(\gamma\left(\mathrm{NH}_{2}\right)\right)$, one $\gamma\left(\mathrm{COO}^{-}\right)$, and finally one $\gamma\left(\mathrm{H}_{2} \mathrm{O}\right)$. From lorentzian fitting of the bands observed in the frequency range $820-920 \mathrm{~cm}^{-1}$ we have assigned the following vibrations: (i) two $\nu_{s}(\mathrm{CC})$ at 913 and $888 \mathrm{~cm}^{-1}$, (ii) one $\gamma\left(\mathrm{NH}_{2}\right)$ at $838 \mathrm{~cm}^{-1}$, and (iii) one $\gamma\left(\mathrm{COO}^{-}\right)$at $823 \mathrm{~cm}^{-1}$. The vibration of $807 \mathrm{~cm}^{-1}$ is assigned to $\gamma\left(\mathrm{H}_{2} \mathrm{O}\right)$, since it is not present in the spectrum of Asn- $h_{5}$ [3]. The methylene rocking vibration was assigned at frequencies around $780 \mathrm{~cm}^{-1}$ for glutamine [14] and DL - serine [17]. Here, we assigned the $\mathrm{r}\left(\mathrm{CH}_{2}\right)$ at $799 \mathrm{~cm}^{-1}$. However, for Asn- $\mathrm{h}_{5}$, Casado et 
al. [3], have assigned the $\mathrm{r}\left(\mathrm{CH}_{2}\right)$ at $874 \mathrm{~cm}^{-1}$. It seems to be a contradiction between our assignment and that proposed in Ref.[3]. In order to verify our assignment, we observe its temperature-dependent behavior in the range $10-300 \mathrm{~K}$ [6]. We observed no modifications in the frequency and linewidth of this mode, which indicates that it is not affected by hydrogen bonds, and indeed it must be assigned to $\mathrm{r}\left(\mathrm{CH}_{2}\right)$. On the basis of correlations with related molecules [13-17] the bands at 648 and $569 \mathrm{~cm}^{-1}$ were assigned as two $\delta\left(\mathrm{COO}^{-}\right)$, while the bands at $664 \mathrm{~cm}^{-1}$ and $603 \mathrm{~cm}^{-1}$ as two $\delta\left(\mathrm{CONH}_{2}\right)$.

There are still 8 bands in the frequency range 180 - $570 \mathrm{~cm}^{-1}$. Five of them are related to torsional $(\tau)$ and bending modes of skeletal structure. The remainder three are assigned to $\tau\left(\mathrm{COO}^{-}\right)$at $200 \mathrm{~cm}^{-1}, \tau$ $\left(\mathrm{NH}_{3}^{+}\right)$at $386 \mathrm{~cm}^{-1}$ and $\tau\left(\mathrm{NH}_{2}\right)$ at $521 \mathrm{~cm}^{-1}$. These results are in good accordance with those reported for other amino acid compounds [3,9,13-17].

\section{Lattice vibration region}

Unfortunately, there are only few reports concerning the investigation on the assignment of lattice vibrations in amino-acids [18-20]. Some bands observed below $190 \mathrm{~cm}^{-1}$ are tentatively assigned to stretching, torsional and skeletal bending vibrations, whereas other spectral lines should be assigned to intermolecular hydrogen bonding between the $\mathrm{NH}_{3}^{+}$and $\mathrm{COO}^{-}$groups in the neighboring molecules. The other types of intermolecular interactions presumably do not contribute significantly to the spectrum as the force acting between hydrocarbon molecules is generally weak, and furthermore the atoms in different MLA molecules are separated greatly from each other.

The following discussion is based on $B_{3}$ symmetry modes showed in Fig. 5. The measured wavenumbers, relative intensities and proposed assignments for the bands observed in this frequency region are summarized in Table 4. The vibrations of $185 \mathrm{~cm}^{-1}$ and $146 \mathrm{~cm}^{-1}$ are assigned to bending vibrations of skeletal structure, whereas, according to Ref.[19], the bands at $138 \mathrm{~cm}^{-1}$, $131 \mathrm{~cm}^{-1}, 118 \mathrm{~cm}^{-1}, 96 \mathrm{~cm}^{-1}, 90 \mathrm{~cm}^{-1}, 82 \mathrm{~cm}^{-1}$ and $54 \mathrm{~cm}^{-1}$ can be tentatively assigned to stretching or bending vibrations of $\left(\mathrm{A}^{\rightarrow}-\mathrm{H}^{\rightarrow} \ldots \leftarrow \mathrm{O}\right)$ hydrogen bonds.

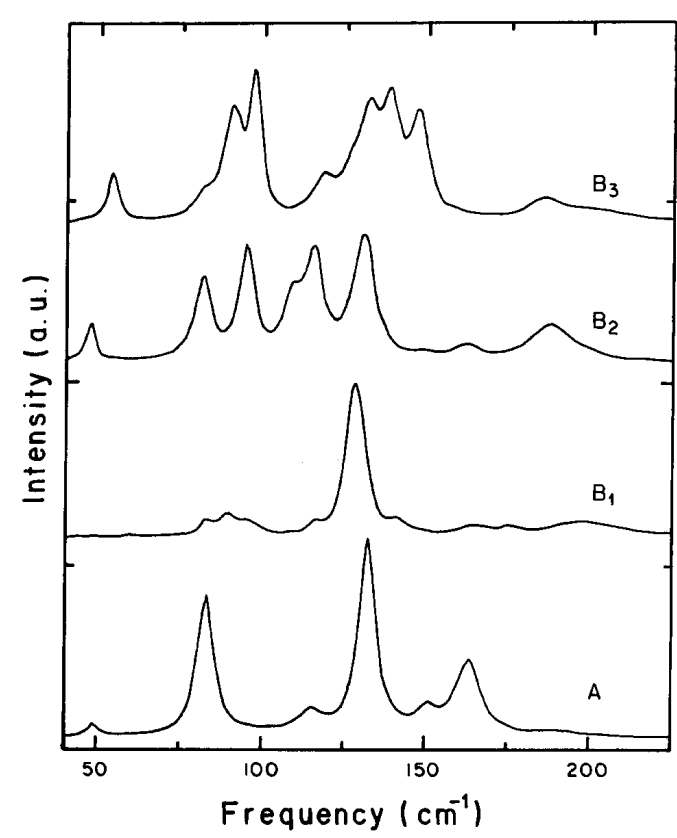

Figure 5. Polarized Raman spectra of MLA for frequencies below $190 \mathrm{~cm}^{-1}$.

\section{Conclusions}

In conclusion we have presented a polarized Raman scattering study of MLA crystals at room temperature. We observed most of the fundamental vibrations expected from the group theory analysis. A general assignment for these fundamental vibrations was proposed on the basis of the detailed analysis of Raman spectra taken at several temperatures in the range $10-$ $300 \mathrm{~K}$ and correlation with similar amino acids. The results confirmed the zwitterionic structure of MLA, since no hydroxyl stretching vibrations were found. The assignments proposed in this work are in good agreement with those previously reported for Asn- $\mathrm{h}_{5}$ by Casado et al. [3]. There are few but important differences between these assignments, namely: (i) the observation of fundamental modes related to the water molecule vibrations; (ii) the correct assignment for $\mathrm{r}\left(\mathrm{CH}_{2}\right)$; (iii) the assignment for $\nu_{s}\left(\mathrm{NH}_{3}^{+}\right)$vibration; and (iv) the tentative assignment for low-frequency vibrations. This agreement was expected since all amino acids ( hydrate or not) already studied, present common structures which are subject to similar environments and bonding distances. Further works for the anharmonic effects induced by temperature changing in some fundamental vibrations associated to hydrogen bonds is in progress. 
TABLE 4. Experimental wavenumbers from the vibration spectra of MLA at $300 \mathrm{~K}$ for frequencies below 190 $\mathrm{cm}^{-1}$.

\begin{tabular}{lllllll}
\hline $\mathrm{z}(\mathrm{xx}) \mathrm{y}$ & $\mathrm{x}(\mathrm{yy}) \mathrm{z}$ & $\mathrm{y}(\mathrm{zz}) \mathrm{x}$ & $\mathrm{y}(\mathrm{xy}) \mathrm{x}$ & $\mathrm{y}(\mathrm{xz}) \mathrm{x}$ & $\mathrm{z}(\mathrm{yz}) \mathrm{x}$ & assignment \\
\hline $191 \mathrm{w}$ & $191 \mathrm{w}$ & $191 \mathrm{w}$ & $197 \mathrm{w}$ & $198 \mathrm{w}$ & $200 \mathrm{w}$ & $\tau\left(\mathrm{CO}_{2}^{-}\right)$ \\
- & - & - & $175 \mathrm{w}$ & $190 \mathrm{~s}$ & $185 \mathrm{~s}$ & $\delta$ (struct) \\
$163 \mathrm{w}$ & $163 \mathrm{w}$ & $163 \mathrm{w}$ & $165 \mathrm{w}$ & $160 \mathrm{w}$ & - & $\delta$ (struct) \\
$150 \mathrm{w}$ & $150 \mathrm{w}$ & $150 \mathrm{w}$ & $141 \mathrm{w}$ & $153 \mathrm{~s}$ & $146 \mathrm{~s}$ & $2 \delta($ struct) \\
$132 \mathrm{vs}$ & $132 \mathrm{vs}$ & $132 \mathrm{vs}$ & $130 \mathrm{vs}$ & $135 \mathrm{~s}$ & $138 \mathrm{~s}$ & \\
- & - & - & $127 \mathrm{vs}$ & $131 \mathrm{~s}$ & $131 \mathrm{~s}$ & \\
$115 \mathrm{w}$ & $115 \mathrm{w}$ & $115 \mathrm{w}$ & $116 \mathrm{~s}$ & $121 \mathrm{~s}$ & $118 \mathrm{w}$ & \\
- & - & - & $96 \mathrm{w}$ & $102 \mathrm{~s}$ & $96 \mathrm{vs}$ & \\
- & - & - & $90 \mathrm{w}$ & $87 \mathrm{vs}$ & $90 \mathrm{vs}$ & \\
$83 \mathrm{~s}$ & $83 \mathrm{~s}$ & $83 \mathrm{~s}$ & $83 \mathrm{w}$ & $82 \mathrm{~s}$ & $82 \mathrm{w}$ & \\
$48 \mathrm{w}$ & $48 \mathrm{w}$ & $48 \mathrm{w}$ & - & $48 \mathrm{vw}$ & $54 \mathrm{~s}$ & \\
\hline $\mathrm{s}=$ strong; & $\mathrm{w}=$ weak; & $\mathrm{v}=$ very and & $\mathrm{sh}=$ shoulder & & & \\
\hline
\end{tabular}

\section{Acknowledgements}

The authors are grateful to Professor Eduardo E. Castellano from Universidade de São Paulo for orienting the MLA crystals used in the experiments. This research was supported by Coordenação de Aperfeiçoamento de Pessoal de Nível Superior (CAPES), Conselho Nacional de Desenvolvimento Científico e Tecnológico $(\mathrm{CNPq})$, and Fundação Cearense de Apoio à Pesquisa (FUNCAP).

\section{References}

1. P. Lund, Nitrogen Metabolism in Mammalian, Applied Science, Barking (1981).

2. D. Garfinkel and J. T. Edsal, J. Am. Chem. Soc. 80, 3818 (1958).

3. J. Casado, J. T. López-Navarrete and F. J. Ramirez, J. Raman Spectrosc. 26, 1003 (1995).

4. M. Ramanadham, S. K. Sikka and R. Chidambaram, Acta Cryst. B28, 3000 (1972).

5. A. J. D. Moreno, P. T. C. Freire, F. E. A. Melo, M. A. Araújo Silva, I. Guedes and J. Mendes-Filho, Solid State Commun. 103, 655 (1997).

6. A. J. D. Moreno, Ph.D Thesis, Universidade Federal do Ceará (1996), unpublished.

7. B. Tell, T. C. Damen and S. P. S. Porto, Phys. Rev. A 144, 771 (1966).
8. G. Herzberg, Infrared and Raman Spectra of Polyatomic Molecules, Van Nostrand Reinhold Co., New York (1945).

9. M. Diem, P. L. Polavarupu, M. Obodi and L. A. Nafie, J. Am. Chem. Soc. 104, 3329 (1982).

10. P. T. C. Freire, F. E. A. Melo and J. Mendes-Filho, J. Raman Spectrosc. 27, 507 (1996).

11. J. T. López-Navarrete, V. Hernández and F. J. Ramirez, Biopolymers 34, 1065 (1994).

12. C. Madec, J. Lauransan and C. GarrigouLagrange, Can. J. Spectrosc. 23, 166 (1978).

13. M. Kakihana, M. Akiyama, T. Naguno and M. Okamoto, Z. Naturforsch., Teil A 43, 774 (1988).

14. P. Dhamelincourt and F. J. Ramirez, Appl. Spectrosc. 47, 446 (1993).

15. J. Arenas and R. Parellada, An. Quim. 66, 283 (1970).

16. B. L. Silva, P. T. C. Freire, F. E. A. Melo, I. Guedes, M. A. Araújo Silva, J. Mendes-Filho and A. J. D. Moreno, Braz. J. Phys. 28, 19 (1998).

17. K. Machida, A. Kagayama, Y. Saito, Y. Kuroda and T. Uno, Spectrochim. Acta A 33, 569 (1977).

18. S. F. Fischer, G. L. Hofacker and M. A. Ratner, J. Chem. Phys. 52, 1934 (1970).

19. C. H. Wang and R. D. Storms, J. Chem. Phys. 55, 3291 (1971).

20. S. Bratos, J. Chem. Phys. 63, 3499 (1975). 